\title{
Major Metabolic Diseases Affecting Cows in Transition Period
}

\author{
Leilson R. Bezerra ${ }^{1}$, Cezario B. de Oliveira Neto ${ }^{1}$, Marcos J. de Araújo ${ }^{1}$, Ricardo L. Edvan ${ }^{1}$, \\ Wagner D. C. de Oliveira ${ }^{1} \&$ Fabrício B. Pereira ${ }^{1}$ \\ ${ }^{1}$ School of Zootecnia, Federal University of Piauí, Bom Jesus, Piauí, Brazil \\ Correspondence: Leilson Rocha Bezerra, Campus Professora Cinobelina Elvas, University Federal of Piauí, BR \\ 135, km03, Bairro Planalto Horizonte, Bom Jesus, Piauí State, Brazi. Tel: 89-9907-0961. Email: \\ leilson@ufpi.edu.br
}

\author{
Received: April 15, 2014 Accepted: May 19, 2014 Online Published: May 31, 2014 \\ doi:10.5539/ijb.v6n3p85 URL: http://dx.doi.org/10.5539/ijb.v6n3p85
}

\begin{abstract}
The aim of this study was to perform a literary review on the main metabolic diseases affecting cows during the transition period. The heat increment promoted by higher energy demand that occurs during the transition period between the end of lactation and early management, combined with low dry matter intake due to fetal growth major and consequent reduced ability of the rumen, make the dairy cow highly susceptible to the metabolic diseases ketosis, milk fever and hepatic lipidosis. The increase in blood concentrations of non-esterifies fatty acids during this transition period appear to be linked to the onset of these disorders and this can be explained by the high energy mobilization because of the negative energy balance. Diets with high energy density during this period are extremely necessary to minimize the effects of negative energy balance. In addition it is recommended to feed the animals with foods smaller particles because the capacity of the rumen is reduced. It also recommends the provision of lipid sources such as protected fat and vegetable oils that do not degrade the ruminal microorganisms and even precursors of glucose, such as propylene glycol or starchy concentrates, and not by lipid.
\end{abstract}

Keywords: diagnosis, fatty liver syndrome, ketosis, milk fever, postpartum, ruminant

\section{Introduction}

The success of the production cycle of a cow is determined by its production level, the postpartum recovery reproductive function and absence of pathology. Undoubtedly, the achievement of these objectives depends largely on the state of animal in its early days postpartum. So much so, that the level of production, the level of intake and blood parameters (NEFA, ketone bodies) in the first week postpartum are good indicators of the quality of initiating lactation (Grummer, Mashek, \& Hayirli, 2004).

The energy balance is the result of the difference between the needs of the animal and food contributions. During last 2-4 weeks of gestation there is an increase substantial energy requirements due to fetal development and the needs of colostrum synthesis. This is accompanied by a decrease in the ingestion of materials dry. These two circumstances are often responsible for the development of a negative energy balance that initiates A few weeks before delivery. Cattle have the ability to compensate for deficits food energy through the mobilization of body fat. However, an excess mobilization of fat leads to disease and reproductive problems

The metabolic diseases or disorders of production are caused by an imbalance of nutrients that enter the animal organism (glicídeos, proteins, minerals, and water), your metabolism and graduates through feces, urine, milk and fetus. Nutritional imbalances affecting livestock are produced because the supply or use of foods is not meet nutritional requirements for maintenance, growth, production, reproduction (Martinez et al., 2014). When these imbalances are of short duration and are not too severe, the metabolism of the animal can compensate by using their body reserves. However, if the imbalance is severe or moderate but persistent animal body depletes its reserves and disease occurs (Wittwer, 2000). Unfortunately, most of these diseases has an effect difficult to perceive and act by limiting the production of the species of a persistently causing a decrease in the profitability of livestock enterprise.

The transition period consists of two phases, the first being formed by last three weeks before calving and the second by the first three weeks postpartum. This period is marked by changes, some of these are related to 
Alterations Increases in energy requirements driven by both fetal needs and lactogenesis, endocrine and metabolic preparing cows for childbirth and lactation (Morgante et al., 2012; Piccione et al., 2012).

According to most recent National Animal Health Monitoring System for dairy cattle (National Animal Health Monitoring System, 2008), leading causes of morbidity in dairy cattle are clinical mastitis, lameness, infertility, retained placenta, milk fever, reproductive problems, and displaced abomasum. Of cows removed from herds, about $53 \%$ leave for one or more of the above reasons. Additionally, the rate of mortality of cows in U.S. dairy herds is nearly $6 \%$, with $43 \%$ of these related to periparturient health issues, and likely a large portion of those classified as "unknown" (25\%) occurring as a result of complications from the above. Overall, $16.2 \%$ of the cows that are permanently removed from a dairy herd are removed before 50 days in milk. These cows represent losses before the most profitable period of lactation. The relationship of the above disorders to excess prepartum body condition score (BCS) has been documented by numerous researchers and extensively reviewed (Bewley \& Schultz, 2008). Briefly, cows with excessive body condition at calving, or excessive weight loss after calving, demonstrate overall decreased reproductive performance and increased likelihood of dystocia, retained placenta, metritis, milk fever, cystic ovaries, lameness, and mastitis as well as metabolic disorders, fatty liver, and ketosis.

\section{Development}

\subsection{Ketosis and Fatty Liver Syndrome}

Ketosis and Fatty Liver Syndrom is a metabolic disorder which often goes undiagnosed and leads to constricted performance and an impairment of general condition. It's primarily occurs 2-7 weeks after calving (Gillund, Reksen, Grohn, \& Karlberg, 2001) and occurs in consequence of negative energy balance, which will promote fat ana mobilizaçlão form of triacylglycerides (TGL). Before reaching the liver, TGL lose ester molecule in order to facilitate the conduction blood. Upon arriving at the liver TGL will be transformed into ketone bodies ketone bodies, acetoacetate $(\mathrm{AcAc})$ and acetone $(\mathrm{Ac})$ can be reduced to $\beta$-hydroxybutyrate $(\mathrm{BHB})$ in an enzymatic reaction or decarboxylated to generate energy (Nielsen \& Ingvartsen, 2004).

In early lactation, dairy cows high-yielding production suffer a variety of metabolic changes derived from energy deficiency, due to poor dry matter ingestion and high milk production, which are factors that predispose to ketosis (Chapinal et al., 2011) . A study to describe the prevalence of primary subclinical ketosis in New Zealand demonstrated age and calving interval are predisposing factors to the onset of ketosis (Compton, McDougall, Young \& Bryan, 2014). Already Fatty Liver represents the major factor predisposing body condition score because fat and very fat cows have to have the disorder in the postpartum period. Furthermore, the Fatty liver may be a secondary complication to the cow to have a negative energy balance. Once developed fatty liver, and due to the low rate of export triglyceride in the form of lipoproteins, fatty liver persist for a long period. Reduction of fatty deposits in the liver is usually initiated when the cow enters positive energy balance, and end exhausted in the course of several weeks (Chapinal et al., 2012).

In the period between the end of late gestation and early lactation, there is a marked change from the dry matter intake by females. In cows reduction in consumption in this period is even more pronounced than for the heifers as shown in Figure 1. Over the first 30 days postpartum, when there is the peak of lactation, also observed consumption capacity suboptimal mobilization of body reserves for milk production, and often weight loss. The observed negative energy balance is due to insufficient nutrients necessary for lactation by dietary intake, because at this stage there is a priority of nutrients by the mammary gland (Leroy, Vanholde, Van Knegsel, Garcia-Ispierto \& Bols, 2008) mediated by limiting the consumption capacity, causing a serious change in blood metabolites and hematological profile of animals (Piccione et al., 2012; Bezerra et al., 2013). With the advance of lactation (60 days postpartum), known as an intermediary period, milk production begins to decrease in the order of $2.5 \%$ per week, while the voluntary intake increases gradually. Finally, at 90 days post partum, post- peak DM intake milk production continues to decrease gradually (NRC, 2008).

These responses, exaggerated by moderate under nutrition status in pregnant animals, are mediated by reduced tissue sensitivity and responsiveness to insulin, associated with decreased tissue expression of the insulin-responsive facilitative glucose transporter (GLUT4) (Bell \& Bauman 1997). Peripheal tissue responses to insulin remain severely attenuated during early lactation but recover as the animal progresses through mid-lactation (Guesnet, Massoud \& Demarne 1991, Bell \& Bauman 1997, Sasaki 2002). Thus, during the period of NEB, key hormone expression and tissue responsiveness alter to increase lipolysis and decrease lipogenesis, causing high levels of non-esterified fatty acids (NEFA) and $\beta$-hydroxybutyrate (BHB) concentration which are indicative of lipid mobilization and fatty acid oxidation (Sakha, Ameri \& Rohbakhsh, 2006, Wathes et al., 2009). Excessive fat mobilization can induce an imbalance in he patic carbohydrate and fat metabolism, which may result in ketosis (Goff \& Horst, 1997). 


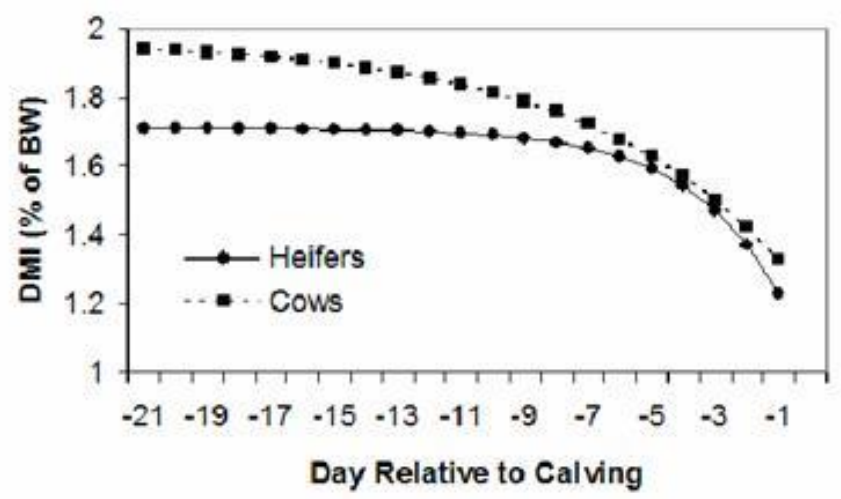

Figure 1. Dry matter intake comparative between cows and heifers during the transition period (Grummer, Mashek \& Hayirli, 2004)

Fatty liver occurs when blood levels are elevated NEFA. This is dramatically raising birth. The liver's ability to grasp the NEFA is proportional to their concentration in the blood. The NEFA taken up by the liver are esterified to triglycerides or oxidized in mitochondria or peroxisomes (microsomes). TGL can be stored or exported as part of a low density lipoprotein. Compared with other species, the export capacity of liver triglycerides in ruminants is low, not knowing the cause. Under circumstances where an increase is produced in the liver uptake of NEFA (for example, when there are low levels of glucose and insulin in the blood), the esterification of fatty acids and accumulation of triglycerides in the liver occurs (Andresen, 2001). Complete oxidation of NEFA forms CO2. Incomplete oxidation produces ketone bodies (especially acetoacetate and beta- hydroxy - butyrate. Formation of ketone bodies is also favored when blood levels of glucose and insulin are low, partly due to increased mobilization of fatty acids from tissue adipose. Low levels of insulin may increase the oxidation of fatty acids by reduction in malonyl -CoA concentration in hepatocytes and reduced sensitivity of the -1 carnitine palmitoiltrasferasa action of malonyl -CoA. Carnitine palmitoyltransferase - 1 is responsible for the translocation of fatty acids from the cytosol to the mitochondria for oxidation; action is inhibited by malonyl - CoA. Propionic acid is anti - ketogenic, probably due to its indirect effects in promoting insulin secretion and its direct effects on hepatic metabolism.

In the case of Fatty Liver Syndrome the deposition of TAG in liver is the consequence of mobilization of NEFA from adipose tissue exceeding capabilities of liver for oxidation and secretion of lipids (Gross, Schwarz, Eder, Van Dorland \& Bruckmaier, 2013). Cows with fatty liver have greater adipose stores and mobilize more TAG, which leads to greater plasma NEFA concentrations, because adipose tissue from cows with fatty liver is less responsive to lipogenic substances and more responsive to lipolytic substances. Furthermore, cows with fatty liver have decreased fatty acid oxidation, hepatic apolipoprotein synthesis and lipid secretion, as indicated by decreased plasma apolipoprotein and lipid concentrations and decreased serum lecithin: cholesterol acyltransferase (LCAT) activity (Bobe, Young \& Beitz, 2004). Besides disturbances in lipid metabolism, cows with fatty liver also have disturbances in glucose metabolism: Cows with fatty liver are either hyperinsulinemic-hyperglycemic or hypoinsulinemic-hypoglycemic (Holtenius, 1991), because either peripheral glucose uptake is decreased, indicating insulin resistance, or insulin and glucagon secretion and, therefore, hepatic gluconeogenesis are decreased. Furthermore, plasma amino acids are decreased. In summary, the availability of glucose, amino acids, and lipids for peripheral tissues is decreased in cows with fatty liver.

The diagnosis is made by clinical history, clinical signs and laboratory tests. The confirmation must be made by measurement of serum blood glucose $(<50 \mathrm{mg} / 100 \mathrm{ml})$ b-hydroxybutyrate $(>14.4 \mathrm{mg} / \mathrm{dl})$. The presence of ketones in the urine ("Ketostick") also assists in confirmation. The subclinical ketosis is characterized by a $\beta$-hydroxybutyrate (BHB) concentration in blood serum and milk (Figure 2; Herdt, Dart \& Neuder, 2001). To generate this metabolic situation, an animal model was created. The model, based on group-specific interaction of dietary energy supply and body condition, is appropriate for testing the medical effectiveness of treating this kind of ketosis and its concomitants (Denis-Robichaud, Dubuc, Lefebvre \& DesCôteaux, 2014; Campos, González, Coldebella \& Lacerda, 2005). Research has been tested other forms of diagnosis as a magnetic resonance-based metabolomics. Sun et al. (2014) observed that plasma ${ }^{1} \mathrm{H}$-nuclear magnetic resonance-based metabolomics, coupled with pattern recognition analytical methods, not only has the sensitivity and specificity to distinguish 
cows with clinical and subclinical ketosis from healthy controls, but also has the potential to be developed into a clinically useful diagnostic tool that could contribute to a further understanding of the disease mechanisms.

According Mahrt, Burfeind \& Heuwieser (2014) to measure BHBA, blood samples of continuously fed dairy cows can be drawn at any time of the day. A single measurement provides very good test characteristics for on-farm conditions. Blood samples for BHBA measurement should be drawn from the jugular vein or tail vessels; the mammary vein should not be used for this purpose.

In search for accuracy of milk ketone bodies from flow-injection analysis for the diagnosis of hyperketonemia in dairy cows. Denis-Robichaud, Dubuc, Lefebvre, and DesCôteaux (2014) observed that accounted for milk BHBA and milk acetone values simultaneously had the highest accuracy of all tested models for predicting hyperketonemia. These results support that milk BHBA and milk acetone values from flow-injection analysis are accurate diagnostic tools for hyperketonemia in dairy cows and could potentially be used for herd-level hyperketonemia surveillance programs.

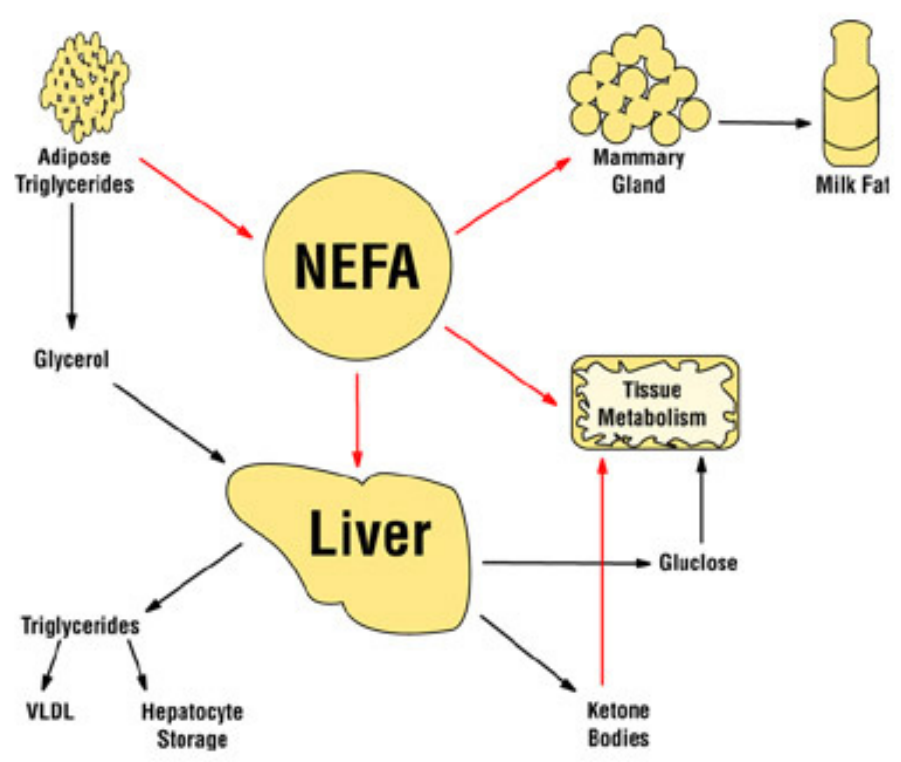

Figure 2: Non-esterfied fatty acids can be used as a sensitive indicator of energy balance in blood and milk. (Herdt, Dart \& Neuder, 2001)

The evaluation of NEFA and BHB represents a strategy for the monitoring of subclinical ketosis and prepartum negative energy balance in dairy cows (Contreras, O'Boyle, Herdt, \& Sordillo, 2010). The intravenous Glucose tolerance test (GTT) was useful o studying the physiological adaptation of animals to transition period since it produced a specific insulin response path (Morgante et al., 2012)

Treatment should be carried out with the $40 \%$ glucose, glucocorticoids, propylene glycol, sodium propionate and B12 (greater propionate production). Should avoid excessive weight loss at calving (management body condition score). The transition of diets should be performed with caution, always carefully to ensure gradual changes in the types of crops, gradual changes in the amounts of concentrates to supply adequate energy levels at different stages of production. Supplementation with niacin (6-12g / d) works best when forages and grains are supplied separately (largest fluctuation of glucose, insulin, NEFA and ketones in the blood) (Wittwer, 2000).

Recent research has demonstrated a reduction in lipoprotein assembly and secretion of TGL can promote deficits choline in non-ruminants. The addition of other methyl donors such as methionine serves to prevent the accumulation of lipids in the liver in mice, perhaps as substrates for the synthesis of choline. Currently there is considerable interest in the use of choline and related compounds to reduce fatty liver associated with the onset of labor. Rumen on the hill is a promise to modulate the metabolism of cows in transition period and reduce the incidence and severity of fatty liver at calving (Figure 3). The frequency response of a significant positive milk production of rumen-protected choline is observed in $50 \%$ of studies. Metabolic responses to rumen-protected choline have been mistaken. The predictable response to feeding rumen protected choline may depend on the basal 
diet, the supply of other B vitamins and related factors, and other management factors, including body condition score of cows entering the transition period (Donkin, 2011). Moreover, the formation of lipoproteins in the liver is not only in dependence of nutrients such as choline but a number of related factors to fat utilization by ruminants that are sensitive to these nutrients because of the deleterious effect that it promotes rumen. Thus, despite advances, little can be said about reducing the incidence of fatty liver by the use of this substance.

The prevention is determined that intervention with glucagon as a treatment/prevention of fatty liver is most effective within 14 days after parturition. The results demonstrated that subcutaneous injections of glucagon of 7.5 and $15 \mathrm{mg} / \mathrm{d}$ starting at $2 \mathrm{~d}$ postpartum are sufficient for fatty liver prevention; however, some cows developed fatty liver already at $\mathrm{d} 2$ postpartum. Previous results confirm (Osman et al., 2008) showing that prenatally and subcutaneously injected glucagon will decrease markedly the accumulation of lipid in the liver of the post parturient dairy cow. Daily administration of the same amount $(15 \mathrm{mg} /$ day $)$ of glucagon for several days prenatally in a limited number of cows was effective in preventing fatty liver during the early post parturient period.

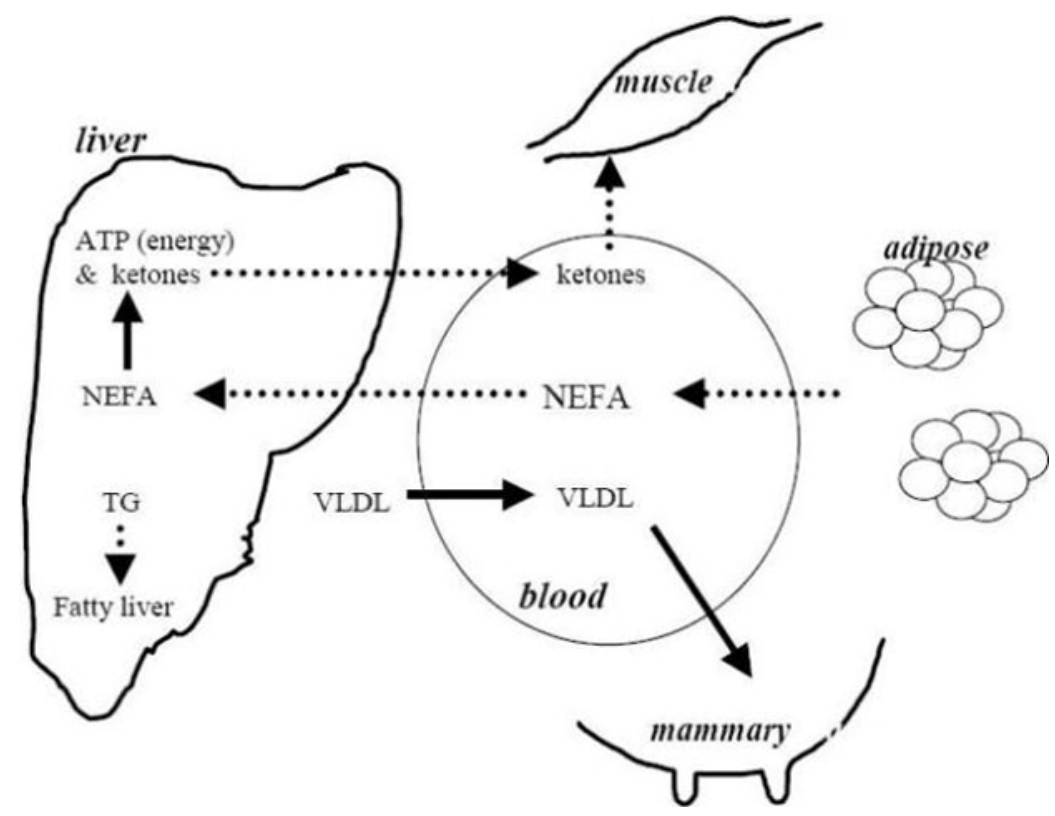

Figure 3. Fat mobilization occurred in cases of fatty liver syndrome or hepatic lipidosis and formation of fat globules in the mammary gland

\subsection{Hypocalcemia Dairy Cow or Milk Fever}

Hypocalcemia is particularly amenable to strategies tailored to individual cows or targeted groups of cows. First, a substantial proportion of cows are affected by hypocalcemia. The birth and early lactation are periods of too much stress for dairy cows due to the large metabolic challenges that occur in this period. During the last 2 weeks pre-calving, dairy cows are usually in negative energy balance and calcium and, in the last days before calving, the balance of other nutrients such as protein, vitamins and minerals may also be compromised. This reduction in serum calcium concentrations usually occurs about 12 to 24 hours after calving (Figure 4, Kimura, Reinhardt \& Goff, 2006; Goff, 2008), where cases of hypocalcemia are more frequent and the most predisposing cows heifers.

Also known as milk fever or puerperal paresis, hypocalcemia is a metabolic-nutritional disease caused by the organism insufficiencies in maintaining serum calcium this period constant transformation in cows. It is a metabolic disease that affects cattle, especially animals with high milk production, which is the lowering of serum calcium and a subsequent number of other problems, such as decubitus and paresis, among others. The etiology is varied but the disease is associated with the delivery and early lactation, causing an exponential increase in needs for calcium $(\mathrm{Ca})$. Calcium is a macromineral that has important functions in the body, among them are the bone matrix, the process of muscle contractor and transmission of nerve impulses. The level of calcium in plasma is well regulated, and when the level decreases, the parathyroid gland will excrete parathyroid hormone (PTH) (Oetzel \& Miller, 2012). This increases the mobilization of calcium from the skeleton and also raises the renal threshold for calcium in the kidneys (Goff, Littledike \& Horst, 1986). During the dry period, the supply of calcium through the 
diet is usually more than adequate to maintain homoeostasis without activating the calcium mobilization system (Ramberg, Mayer, Kronfeld, Phang \& Berman, 1970), which is thus usually not activated until parturition. It is the phase most important in the development of milk fever (Kronqvist, Ferneborg, Emanuelson \& Holtenius, 2014; DeGaris \& Lean, 2008).

One of the major complications in the occurrence of hypocalcemia is that as the $\mathrm{Ca}$ is responsible for impulses transmission of nerve and muscle contractions, since the problem set and depending on its severity ie the severity of paresis may happen several other secondary disorders of order productive or reproductive due to this muscle inactivity, can cite among others retained placenta, metritis, ruminal acidosis, ketosis, due also to the reduction of dry matter intake and negative energy balance (Goff, 2008; Oetzel, 2011).

The cause is the deficiency of $\mathrm{Ca}$ in the early period of lactation. The concentration of plasma calcium is coordinated by action of calciotropic parathyroid hormone (PTH) and 1.25-dihydroxyvitamin D3 [1.25 (OH) 2D3] which are produced in response to hypocalcemia, acting to increase the intake of calcium in the pool plasma. Any decrease in serum calcium stimulates parathyroid gland to secrete PTH which, within minutes, increase renal calcium reabsorption from the glomerular filtrate. If the decreased plasma calcium is small, calcium returns to normal levels and PTH returned to their baseline levels. However, if the calcium drained plasma pool is in large quantities, the continued secretion of PTH stimulates resorption of calcium from bone For a long time it was considered that the tail of the disorder was given due to a failure to respond to release PTH. However, further studies demonstrated that these glands were able to respond to increased demand for calcium, even in cows with puerperal hypocalcemia. Currently it is known that the pathogenesis of the disease is much more associated with the action of PTH on cells responsible for demineralization (osteoclasts), cells of the intestine responsible for absorption and kidney cells responsible for the reabsorption of calcium in the tubules. Factors such as the world Production of milk, age and race are predisposing cows to have the disturbance, since cows for producing more secreted more calcium and should have efficient metabolism to meet increased demand. The great demand of calcium in early lactation to produce 10 liters of colostrum (colostrum formation begins 30 days before calving) cow loses $23 \mathrm{~g}$ of calcium in a single milking $(2.3 \mathrm{~g} / \mathrm{L})$ which is about nine times more present in the plasma compartment. The calcium lost from the plasma compartment should be replaced by intestinal calcium absorbed and bone reabsorption. During the dry season these mechanisms are inactive, and all cows undergo hypocalcemia in the first days after birth until the intestines and bones are adapted. The adaptation starts with increased PTH and $1,25-(\mathrm{OH}) 2 \mathrm{D}$ at the beginning of hypocalcemia. About 24 hours of stimulation of $1,25-(\mathrm{OH}) 2 \mathrm{D}$ is required for intestinal calcium transport increase significantly. Bone reabsorption (osteoclast recruitment and activation) is not increased until 48 hours after the stimulation of PTH. In cows with parturient paresis this adaptation to these procedures may be extended. In these animals the decline of plasma and extracellular calcium determine the death of the animal before intestinal and bone adaptation (Radostits, Gay, Blood \& Hinchcliff, 2002).

Hypocalcemia may or may not show clinical signs. Studies show that many cases of milk fever, animals do not externalize the clinical signs. The most severe hypocalcemia, said clinic $(\mathrm{Ca}<5 \mathrm{mg} / \mathrm{dl})$, has very serious economic point of view because if not rapidly controlled may lead to loss of the affected animal; On the other hand, subclinical hypocalcemia assumes a more insidious role leading to loss of production and fertility. Subclinical hypocalcemia in which concentrations of calcium in the blood does not decline as severely affects about $50 \%$ of lactating dairy cows. If the animals are supplemented with minerals to reduce the risk of milk fever the hypocalcemic percentage of cows is reduced to about 15 to $25 \%$ (Oetzel, 2011).

Regarding the clinical signs of the disease in the stage I, the cow is not yet paresis. At this stage of puerperal hypocalcemia, hypersensitivity conductors nerves and muscles occurs, may cause excitement, muscle tremors, anorexia, ataxia, and general debility. The animal does not want to move, do not feed, but often body temperature is normal and may remain in this stage for hours. The stage II is the prodromica phase of the disease and is characterized by prostration and external decumbency. The tetania observed in the first phase is replaced by prolonged external decumbency with the animal unable to stand, displaying paresis, dry muzzle, cold extremities and temperature above normal $\left(36.5\right.$ to $\left.38^{\circ} \mathrm{C}\right)$. The artery pulse is weak, barely audible heart sounds and moderate heart frequency (to $80 / \mathrm{min}$ ). It is observed absence of ruminal stasis and movements which can lead to a secondary bloat. The stage III is the most advanced, the animal enters and completes lateral decubitus sagging. Cardiac depression is severe and irregular and almost imperceptible pulse, breathing is shallow and diminished. Untreated animals die peacefully with shock in a state of complete collapse (Goff, 1999; Oetzel, 2011).

The diagnosis of milk fever is given based on the history of the animal at birth, age of dam and in the concentrations of calcium in the blood. The decrease in serum levels of magnesium and phosphorus may also be associated. Blood cell count may be some changes as eosinopenia, neutrophilia and lymphopenia suggestive of adrenocortical hyperactivity, but are nonspecific changes. Because of the symptoms is necessary to perform 
diagnosis differs in relation to hepatic steatosis, septic endometritis, mastitis and acute rumen acidosis. Calcium levels may appear below $5 \mathrm{mg} / \mathrm{dl}$, but with less than $7 \mathrm{mg} / \mathrm{dl}$ levels, the animals have demonstrated clinical signs (Figure 4).

The treatment should be carried out as quickly as possible. Animals should be treated as soon as possible. The calcium treated by oral route is the best approach to hypocalcemia cows that are still standing, and the absorption into your bloodstream in about 30 minutes supplementation (Goff \& Horst, 1993). The intravenous administration (IV) calcium is not recommended for the treatment of cows that are still standing (Oetzel, 2011), since this application if not done correctly can result in dead animal by cardiac complication. Cows treated with calcium IV often suffer a relapse hypocalcemic 12 to 18 hours later (Curtis, Cote, McLennan, Smart \& Rowe, 1978; Thilsing Hansen, Jørgensen, \& Østergaard, 2002). For cows in stage II and III of milk fever should be treated immediately with a slow IV administration of $500 \mathrm{ml}$ of a solution of calcium gluconate $23 \%$. This gives $10.8 \mathrm{~g}$ of elemental calcium, which is more than sufficient to correct the deficit whole cow's calcium (about 4 to 6 grams).

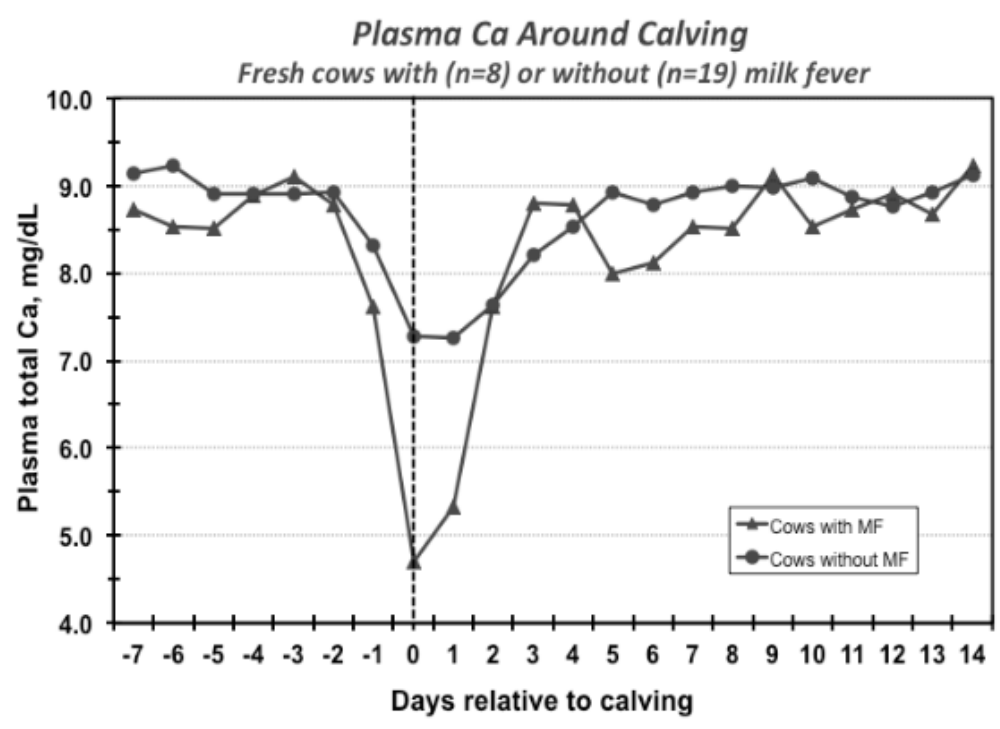

Figure 4. Period of greatest clinical occurrence of milk fever in cows post calving (Adapted Kimura et al. 2006)

Prevention should be performed with the mineral at ease and even forced supplementation during the transition period. In addition to the findings of a larger number of micro minerals essential to functioning of the animal organism, studies have also addressed the relationship between cations and anions present in a certain diet aiding in the metabolic processes of the animal (e.g., acid-base balance) in a particular production phase, thus the anionic and cationic diets have been widely researched and used in animal production, mainly in feeding cows pre calving, animal class often neglected because the producers are not producing milk and consequently does not contributed directly in net income from property (Oetzel, 2004). One of the main aims of using anionic diets in cows during transition period is control subclinical hypocalcemia, milk fever or puerperal paresis. Hypocalcemia is characterized by rapid depletion of blood calcium levels due to the large demand for calcium to the mammary gland in early lactation. The hormones responsible the absorption of calcium in the intestine so as bones, is low in activity due to small calcium requirement during the dry period. From the moment in which animal has one hypocalcemia, increase the incidence of other metabolic disorders such as mastitis, metritis, uterine prolapsed, retained placenta and ketosis, since calcium is a major responsible for muscle contraction and hence the mineral uterine atony and disposal the placenta.

Sakha, Mahmoudi \& Nadalian (2014) in study to determine the effects of varying dietary cation-anion differences (DCAD) in prepartum period on milk fever, subclinical hypocalcemia and negative energy balance in dairy cows showed that use of anionic diets during three weeks before calving can protect dairy cows from clinical and subclinical hypocalcemia by increasing the calcium level in serum. To reduce the postpartum negative energy balance, replacement of anionic diet by cationic ions soon after calving is suggested (Sakha, Mahmoudi, \& Nadalian, 2014). 


\section{Conclusions}

Metabolic diseases are of great economic impact; it usually affects the animals about to reach their maximum potential production. Food consumption cannot be harmed in the coming days to calving and early lactation, since this is a critical period in the nutrition of females. Is any factor that restricts food intake at this stage (such as milk fever or ketosis) increases the metabolism of body fat, when the animal has in order to obtain energy, with consequent accumulation of fat in the liver immobilized, directly affecting the deficit power of females.

It is accepted that reproduction is important for the profitability of dairy farms, and nutritional status and metabolic health are both associated with successful reproduction. Cows that experience periparturient problems have delayed return to ovulation, lower pregnancy per insemination, and increased pregnancy loss. Therefore, implementing nutritional and health programs that reduce the risk of metabolic disturbances are expected to not only improve cow health, but also enhance fertility. Low nutrient intake coupled with high energy demand during the transition period will increase the risk of occurrence of metabolic disorders. Strategies to manipulate peripartum metabolic health involve dietary formulation to minimize the degree and extent of negative nutrient balance, improve $\mathrm{Ca}$ homeostasis, and minimize the severity of negative energy balance.

\section{References}

Andresen, S. H. (2001). Vacas secas y en Transición. Rev. investig. vet. Perú, 12(2), 38-46.

Bell, A. W., \& Bauman, D. E. (1997). Adaptations of Glucose Metabolism During Pregnancy and Lactation. $J$ Mammary Gland Biol Neoplasia, 2, 265-278. http://dx.doi.org/10.1023/A:1026336505343

Bewley, J. M., \& Schutz, M. M. (2008). Review: An interdisciplinary review of body condition scoring for dairy cattle. Prof. Anim. Sci, 24, 507-529.

Bezerra, L. R., Torreão, J. N. C., Marques, C. A. T., Machado, L. P., Araújo, M. J., \& Veiga A. M. S. (2013). Influence of concentrate supplementation and the animal category in the hemogram of Morada Nova sheep. Arquivo Brasileiro de Medicina Veterinária Zootecnia, 65(6), 1738-1744. http://dx.doi.org/10.1590/S0102-09352013000600022

Bobe, G., Young, J. W., \& Beitz, D. C. (2004). Invited review: Pathology, etiology, prevention, and treatment of fatty liver in dairy cows. Journal of Dairy Science, 87, 3105-3124. http://dx.doi.org/10.3168/ jds.S0022-0302(04)73446-3

Campos, R., González, F., Coldebella, A., \& Lacerda, L. (2005). Determinação de corpos cetônicos na urina como ferramenta para o diagnóstico rápido de cetose subclínica bovina e relação com a composição do leite. Archives of Veterinary Science, 10(2), 49-54.

Chapinal, N., Carson, M. E., LeBlanc, S. J., Leslie, K. E., Godden, S., Capel, M., ... Duffield, T. F. (2012). The association of serum metabolites in the transition period with milk production and early lactation reproductive performance. Journal of Dairy Science, 95, 1301-1309. http://dx.doi.org/10.3168/ jds.2011-4724

Chapinal, N., Carson, M., Duffield, T. F., Capel, M., Godden, S., Overton, M., ... LeBlanc, S. J. (2011). The association of serum metabolites with clinical disease during the transition period. Journal of Dairy Science, 94, 4897-4903. http://dx.doi.org/10.3168/jds.2010-4075

Compton, C. W. R., McDougall, S., Young, L., \& Bryan, M. A. (2014). Prevalence of subclinical ketosis in mainly pasture-grazed dairy cows in New Zealand in early lactation. New Zealand Veterinary Journal, 62(1), http://dx.doi.org/10.1080/00480169.2013.823829

Contreras, G. A., O'Boyle, N. J., Herdt, T. H., \& Sordillo, L. M. (2010). Lipomobilization in periparturient dairy cows influences the composition of plasma nonesterified fatty acids and leukocyte phospholipid fatty acids. Journal of Dairy Science, 93, 2508-2516. http://dx.doi.org/10.3168/jds.2009-2876

Curtis, R. A., Cote, J. F., McLennan, M. C., Smart, J. F., \& Rowe, R. C. (1978). Relationship of methods of treatment to relapse rate and serum levels of calcium and phosphorous in parturient hypocalcaemia. Canadian Veterinary Journal, 19, 155-158.

DeGaris, P. J., \& Lean, I. J. (2008). Milk fever in dairy cows: A review of pathophysiology and control principles. Veterinary Journal, 176, 58-69. http://dx.doi.org/10.1016/j.tvj1.2007.12.029

Denis-Robichaud, J., Dubuc, J., Lefebvre, D., \& DesCôteaux, L. (2014) Accuracy of milk ketone bodies from flow-injection analysis for the diagnosis of hyperketonemia in dairy cows. Journal of Dairy Science. http://dx.doi.org/10.3168/jds.2013-6744 
Donkin, S. S. (2011). Extension Foundation. America's Research-based Learning Network. Rumen-Protected Cholin. May 2011. Retrieved 14 april, 2014, from http://www.extension.org:80/pages/26158/ rumen-protected-choline

Gillund, P., Reksen O., Grohn Y. T., \& Karlberg, K. (2001). Body condition related to ketosis and reproductive performance in Norwegian dairy cows. Journal of Dairy Science, 84, 1390-1396. http://dx.doi.org/10.3168/ jds.S0022-0302(01)70170-1

Goff, J. P. (1999). Treatment of calcium, phosphorus, and magnesium balance disorders. Veterinary. Clin. North Am. Food Animal. Pract., 15, 619-639.

Goff, J. P. (2008). The monitoring, prevention, and treatment of milk fever and subclinical hypocalcemia in dairy cows. Veterinary Journal, 176, 50-57. http://dx.doi.org/10.1016/j.tvj1.2007.12.020

Goff, J. P., \& Horst, R. L. (1993). Oral administration of calcium salts for treatment of hypocalcemia in cattle. Journal of Dairy Science, 76, 101-108. http://dx.doi.org/10.3168/jds.S0022-0302(93)77328-2

Goff, J. P., \& Horst, R. L. (1997). Physiological changes at parturition and their relationship to metabolic disorders. Journal of Dairy Science, 80, 1260-1268. http://dx.doi.org/10.3168/jds.S0022-0302(97)76055-7

Goff, J. P., Littledike, E. T., \& Horst, R. L. (1986). Effect of synthetic bovine parathyroid hormone in dairy cows: prevention of hypocalcemic parturient paresis. Journal of Dairy Science, 69, 2278-2289. http://dx.doi.org/10.3168/jds.S0022-0302(86)80666-X

Gross, J. J., Schwarz, F. J., Eder, K., van Dorland, H. A., \& Bruckmaier, R. M. (2013). Liver fat content and lipid metabolism in dairy cows during early lactation and during a mid-lactation feed restriction. Journal of Dairy Science, 96, 5008-5017. http://dx.doi.org/10.3168/jds.2012-6245

Grummer, R. R., Mashek, D. G., \& Hayirli, A. (2004). Dry matter intake and energy balance in the transition period. Vet Clin North Am Food, Anim Pract, 20, 447-470.

Guesnet, P. M., Massoud, M. J., \& Demarne, Y. (1991). Regulation of adipose tissue metabolism during pregnancy and lactation in the ewe: the role of insulin. Journal Animal Science, 69, 2057-2065.

Herdt, T. H., Dart, B., \& Neuder, L. (2001). Will large dairy herds lead to the revival of metabolic profile testing? Proc Am Assoc Bov Pract, 34, 27-34.

Holtenius, P. (1991). Disturbances in the regulation of energy metabolism around parturition in cows. Mh. Vet.-Med, 46, 795-797.

Kimura, K., Reinhardt, T. A., \& Goff, J. P. (2006). Parturition and hypocalcemia blunts calcium signals in immune

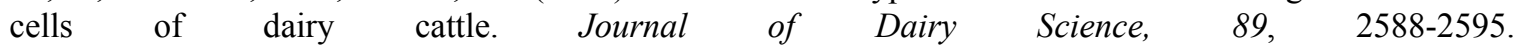
http://dx.doi.org/10.3168/jds.S0022-0302(06)72335-9

Kronqvist, C., Ferneborg, S., Emanuelson, U., \& Holtenius, K. (2014). Effects of pre-partum milking of dairy cows on calcium metabolism at start of milking and at calving. Journal of Animal Physiology and Animal Nutrition, 98(1), 191-196. http://dx.doi.org/10.1111/jpn.12038

Leroy, J. L. M. R., Vanholder, T., Van Knegsel, A.T. M., Garcia-Ispierto, I., \& Bols, P. E. J. (2008). Nutrient Prioritization in Dairy Cows Early Postpartum: Mismatch Between Metabolism and Fertility? Reprod Domest Anim, 43(Suppl.), 96-103. http://dx.doi.org/10.1111/j.1439-0531.2008.01148.x

Mahrt, A., Burfeind, O., \& Heuwieser, W. (2014). Effects of time and sampling location on concentrations of $\beta$-hydroxybutyric acid in dairy cows. Journal of Dairy Science, 97(1), 291-298. http://dx.doi.org/ 10.3168/jds.2013-7099

Martinez, N., Sinedino, L. D. P., Bisinotto, R. S., Ribeiro, E. S., Gomes, G. C., Lima, F. S., ... Santos J. E. P. (2014). Effect of induced subclinical hypocalcemia on physiological responses and neutrophil function in dairy cows. Journal of Dairy Science, 97(2), 874-887. http://dx.doi.org/10.3168/jds.2013-7408

Morgante, M., Gianesella, M., Casella, S., Stelletta, C., Cannizzo, C., Giudice, E., \& Piccione, G. (2012). Response to glucose infusion in pregnant and nonpregnant ewes: changes in plasma glucose and insulin concentrations. Comp Clin Pathol, 21, 961-965. http://dx.doi.org/10.1007/s00580-011-1208-5

National Animal Health Monitoring System. (2008). Dairy 2007 Part I: Reference of Dairy Cattle Health and Management Practices in the United States. 2007. USDA 
Nielsen, N. I., \& Ingvartsen, K. L. (2004). Propylene glycol for dairy cows: A review of the metabolism of propylene glycol and its effects on physiological parameters, feed intake, milk production and risk of ketosis. Anim Feed Sci Technol, 115, 191-213. http://dx.doi.org/10.1016/j.anifeedsci.2004.03.008

Oetzel, G. R. (2004). Monitoring and testing dairy herds for metabolic disease. Veterinary Clin. North Am. Food Animal. Pract, 20, 651-674.

Oetzel, G. R. (2011). Non-infectious diseases: Milk fever. In J. W. Fuquay \& P. L. H. McSweeney (Eds.), Encyclopedia of Dairy Sciences (Vol. 2, pp. 239-245). San Diego: Academic Press.

Oetzel, G. R., \& Miller, B. E. (2012). Effect of oral calcium bolus supplementation on early lactation health and milk yield in commercial dairy herds. Journal of Dairy Science, 95, 7051-7065. http://dx.doi.org/10.3168/jds.2012-5510

Osman, M. A., Allen, P. S., Mehyar, N. A., Bobe, G., Coetzee, J. F., Koehler, K. J., \& Beitz, D. C. (2008). Acute metabolic responses of postpartal dairy cows to subcutaneous glucagon injections, oral glucagon, or both. Journal of Dairy Science, 91, 3311-3322. http://dx.doi.org/10.3168/jds.2008-0997

Piccione, G., Messina, V., Marafioti, S., Casella, S., Giannetto, C., \& Fazio, F. (2012). Changes of some haematochemical parameters in dairy cows during late gestation, post partum, lactation and dry periods. Vet Med Zoot, 58, 59-64.

Radostits, O. M., Gay, C. C., Blood, D. C., \& Hinchcliff, K. W. (2002). Clínica veterinária. Um tratado de doenças dos bovinos, ovinos, suinos, caprinos e eqüinos (Vol. 9, pp. 1737). Rio de Janeiro: Guanabara Koogan.

Ramberg, C. F., Mayer, G. P., Kronfeld, D. S., Phang, J. M., \& Berman, M. (1970) Calcium kinetics in cows during late pregnancy, parturition, and early lactation. The American Journal of Physiology, 219, 1166-1177.

Sakha, M., Ameri, M., \& Rohbakhsh, A. (2006). Changes in blood $\beta$-hydroxybutyrate and glucose concentrations during dry and lactation periods in Iranian Holstein cows. Comp Clin Pathol, 15, 221-226. http://dx.doi.org/10.1007/s00580-006-0650-2

Sakha, M., Mahmoudi, M., \& Nadalian, M. G. (2014). Effects of dietary cation-anion difference on milk fever, subclinical hypocalcemia and negative energy balance in transition dairy cows. Journal Research Opinions in Animal and Veterinary Sciences, 4(2), 69-73.

Sasaki, S. (2002). Mechanism of insulin action on glucose metabolism in ruminants. Anim Sci J, 73, 423-433. http://dx.doi.org/10.1046/j.1344-3941.2002.00059.x

Sun, L. W., Zhang, H. Y., Wu, L., Shu, S., Xia, C., Xu, C., \& Zheng, J.S. (2014). H-Nuclear magnetic resonance-based plasma metabolic profiling of dairy cows with clinical and subclinical ketosis. Journal of Dairy Science, 97(3), 1552-1562. http://dx.doi.org/10.3168/jds.2013-6757

Thilsing-Hansen, T., Jørgensen R. J., \& Østergaard, S. (2002). Milk fever control principles: areview. Acta. Vet. Scand, 43, 1-19.

Wathes, D. C., Cheng, Z., Chowdhury, W., Fenwick, M. A., Fitzpatrick, R., Morris, D. G., ... Murphy, J. J. (2009). Negative energy balance alters global gene expression and immune responses in the uterus of postpartum dairy cows. Physiol Genomics, 39, 1-13. http://dx.doi.org/10.1152/physiolgenomics.00064.2009

Wittwer, F. (2000). Diagnóstico dos desequilíbrios metabólicos de energia em rebanhos bovinos. In F. H. D. González, J. O. Barcellos, H. Ospina, \& L. A. O. Ribeiro (Eds.), Perfil metabólico em ruminantes: seu uso em nutrição e doenças nuricionais. Porto Alegre, Brasil, Gráfica da Universidade Federal do Rio Grande do Sul.

\section{Copyrights}

Copyright for this article is retained by the author(s), with first publication rights granted to the journal.

This is an open-access article distributed under the terms and conditions of the Creative Commons Attribution license (http://creativecommons.org/licenses/by/3.0/). 